\title{
Ontogenic Changes of the Spinal GABAergic Cell Population Are Controlled by the Serotonin (5-HT) System: Implication of 5-HT 1 Receptor Family
}

\author{
Anne-Emilie Allain, Pierre Meyrand, and Pascal Branchereau \\ Laboratoire de Neurobiologie des Réseaux, Université Bordeaux 1 and Centre National de la Recherche Scientifique, Unité Mixte de Recherche 5816, 33405 \\ Talence cedex, France
}

\begin{abstract}
During the development of the nervous system, the acquisition of the GABA neurotransmitter phenotype is crucial for neural networks operation. Although both intrinsic and extrinsic signals such as transcription factors and growth factors have been demonstrated to govern the acquisition of GABA, few data are available concerning the effects of modulatory transmitters expressed by axons that progressively invade emerging neuronal networks. Among such transmitters, serotonin (5-HT) is a good candidate because serotonergic axons innervate the entire CNS at very early stages of development. We have shown previously that descending 5-HT slows the maturation of inhibitory synaptic transmission in the embryonic mouse spinal cord. We now report that 5-HT also regulates the spatiotemporal changes of the GABAergic neuronal population in the mouse spinal cord. Using a quantitative confocal study performed on acute and cultured spinal cords, we find that the GABAergic population matures according to a similar rostrocaudal temporal gradient both in utero and in organotypic culture. Moreover, we show that 5-HT delays the appearance of the spinal GABAergic system. Indeed, in the absence of 5-HT descending inputs or exogenous 5-HT, the GABAergic population matures earlier. In the presence of exogenous 5-HT, the GABA

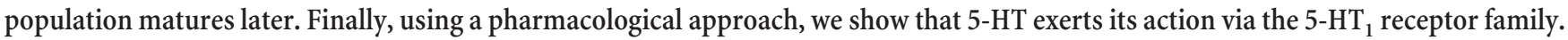
Together, our data suggest that, during the course of the embryonic development, 5-HT descending inputs delay the maturation of lumbar spinal motor networks relative to brachial networks.
\end{abstract}

Key words: mouse; embryonic development; serotonin; GABA phenotype; descending; spinal cord

\section{Introduction}

During the development of the CNS, serotonin (5-HT) is involved in many processes such as those involved in the control of neuronal excitability (Hayashi et al., 1997), neuronal coupling (Rorig and Sutor, 1996), and expression of receptor subtypes (Lauder et al., 2000) and plays a crucial role in the maturation of neuronal networks (for review, see Vinay et al., 2002; Gaspar et al., 2003; Luo et al., 2003; Clarac et al., 2004). However, much less is known about the role of 5-HT in controlling the ontogeny of other neurotransmitters. Among the many neurotransmitters present in the CNS, GABA plays a major role in the operation of neural networks, and interestingly during ontogeny, its functional action switches from an excitatory to an inhibitory mode (Ritter and Zhang, 2000; Ganguly et al., 2001; Gao et al., 2001). This ontogenic switch occurs in all vertebrate CNS regions but at

\footnotetext{
Received April 1, 2005; revised July 18, 2005; accepted July 18, 2005.

This work was supported in part by grants from the Région Aquitaine, the Institut pour la Recherche sur la Moelle épinière et l'Encéphale (Paris, France), and the Ministère de la Recherche et des Nouvelles Technologies (Paris, France). We thank Dr. Fatiha Nothias and Prof. Gerard Tramu for antibodies, Dr. Louis Segu for helpful discussion, and Drs. Blaise Yvert, Jeremy Sullivan, and José Julio Rodríguez Arellano for critical readings of this manuscript.

Correspondence should be addressed to Dr. Pascal Branchereau, Laboratoire de Neurobiologie des Réseaux, Université Bordeaux 1 and Centre National de la Recherche Scientifique, Unité Mixte de Recherche 5816, Avenue des Facultés, 33405 Talence cedex, France. E-mail: p.branchereau@Inr.u-bordeaux1.fr.

DOI:10.1523/JNEUROSCI.2398-05.2005

Copyright $\odot 2005$ Society for Neuroscience $\quad$ 0270-6474/05/258714-11\$15.00/0
}

different stages of development depending on the type of neural network: between embryonic day 13 (E13) and E15 in the mouse spinal cord (Branchereau et al., 2002) and within the first postnatal week in the mouse brainstem pre-Botzinger complex (Ritter and Zhang, 2000).

The ontogenic changes in GABA function have been well documented (Ben-Ari, 2002; Owens and Kriegstein, 2002), as well as the dynamics of the expression of the GABA populations during development (Ma et al., 1992; Binor and Heathcote, 2001; Allain et al., 2004b). Interestingly, the functional switch from excitation to inhibition in the lumbar mouse spinal cord starts to develop concomitantly with a transient peak in the level of the GABA phenotype (i.e., at E14.5) (Branchereau et al., 2002). An important open question remains: How is the expression of the GABA phenotype controlled during development?

Previously, we showed that the transient increase in GABA expression in the mouse spinal cord coincides with the developmental stage at which 5-HT supraspinal descending inputs reach spinal levels (Ballion et al., 2002; Allain et al., 2004b). Additionally, we also demonstrated that the removal of serotonergic innervations accelerates the development of GABA intraspinal inhibitions at the physiological level (Branchereau et al., 2002). The aim of the present study was to determine whether 5-HT descending inputs also regulate the expression of the GABAergic phenotype in the mouse spinal cord. To address this issue, we 

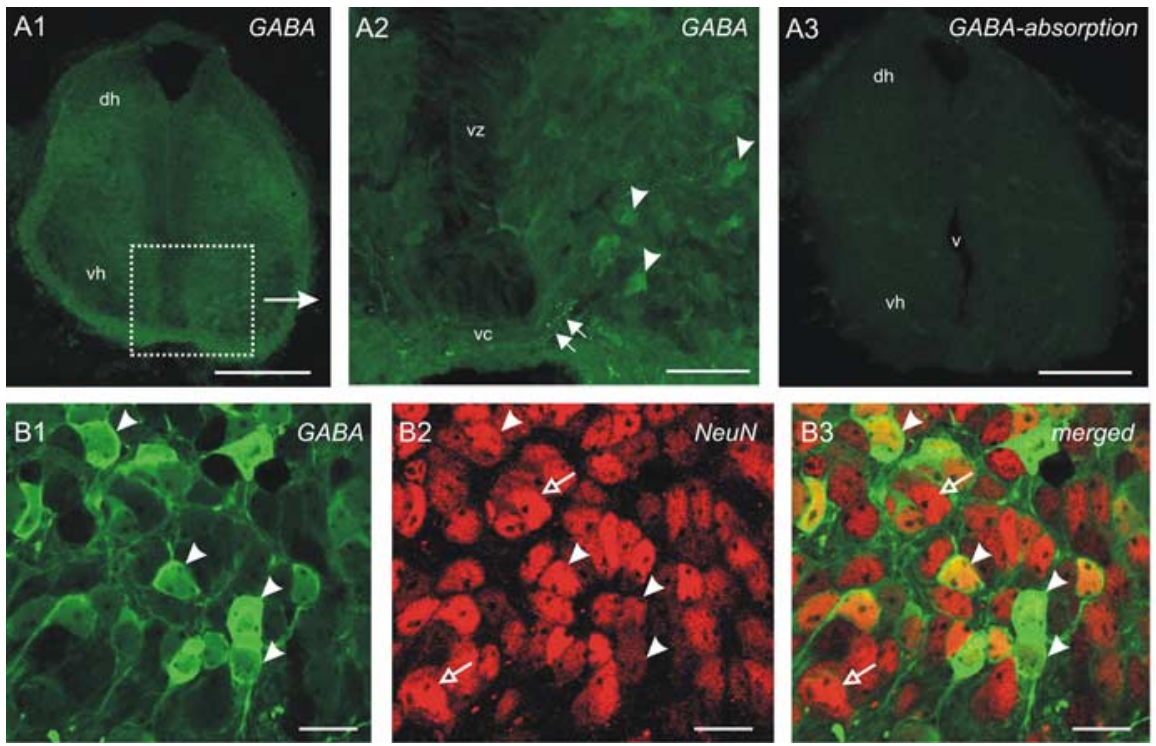

Figure 1. Preabsorption of the primary GABA antiserum $(\mathbf{A 1}-\mathbf{A} \mathbf{3})$ and double GABA/NeuN labeling (B1-B3). $\boldsymbol{A}$ 1, Corona section of the lumbar spinal cord at E13.5 treated with the GABA antiserum. The dotted square corresponds to the ventral area shown in $\mathbf{A 2}$ at a higher magnification. A2, Perikarya as well as neurites show intense immunostaining for GABA (arrowheads and arrows, respectively). $\mathbf{A 3}, \mathrm{A}$ section incubated with GABA antiserum pretreated with $40 \mu \mathrm{M} G A B A-$ glutaraldehyde-BSA conjugate. The pretreatment results in a complete loss of staining. $\boldsymbol{B} 1-\mathbf{B} 3$, Somata immunoreactive for GABA (green, arrowheads; $\boldsymbol{B} 1$ ) and NeuN (red, open arrows and arrowheads; $B 2$ ) in a 4 DIC organotypic culture. The merged image in $\mathbf{B} 3$ indicates that all GABA-IR somata are also immunoreactive for NeuN (yellow, arrowheads), whereas numerous other NeuN-IR somata are not GABA positive (open arrows). dh, Dorsal horn; v, ventricle; vc, ventral commissure; vh, ventral horn; vz, ventricular zone. Scale bars: $\boldsymbol{A 1}$, A3, $200 \mu \mathrm{m} ; A 2,50 \mu \mathrm{m} ; B$ 1-B3, $20 \mu \mathrm{m}$.

used the entire mouse spinal cord maintained in organotypic culture. This unique preparation allows access to the neuronal spinal populations and the manipulation of descending inputs from supraspinal sources (Branchereau et al., 2002).

We provide evidence that, in cultured embryonic mouse spinal cords, the GABAergic population expresses a transient increase in number that occurs with a rostrocaudal delay. We show that, as in vivo, the transient GABA expression appears concomitantly with the arrival of supraspinal 5-HT descending terminals. We demonstrate that 5-HT controls the maturation of this population by delaying its transient increase. Finally, we show that this control specifically operates through an activation of the $5-\mathrm{HT}_{1}$ receptor family. A preliminary report of this study was published in abstract form (Allain et al., 2004a).

\section{Materials and Methods}

Animals and isolation of spinal cords. Pregnant adult and newborn OF1 mice (Charles River Laboratories, St. Germain sur L'Arbresle, France) were maintained and killed according to protocols approved by the European Community Council and conforming to the National Institutes of Health Guidelines for the Care and Use of Laboratory Animals. E0.5 corresponded to the day following the mating night (i.e., day 0.5 of gestation) (confirmed by the observation of a vaginal plug by Charles River Laboratories), and postnatal day 0 (P0) corresponded to the date of birth. Experiments were performed on embryos at E11.5, E13.5, E15.5, and E17.5 and on newborn mice at P0. Embryos were removed surgically from pregnant mice previously anesthetized with diethyl ether. Embryos were rinsed with Dulbecco's PBS at $6-8^{\circ} \mathrm{C}$, and their spinal cords with dorsal root ganglions and meninges were removed. The spinal cords were placed ventral-side down in $35 \mathrm{~mm}$ Falcon dishes, previously coated with Sylgard (Dow Corning, Midland, MI), containing $300 \mu$ l of PBS. Spinal cords were placed ventral-side down on the substrate to allow the opening of the dorsal side at the level of the dorsal fissure. In this study, 483 embryos from 116 pregnant females and six P0 pups were used.

Organotypic cultures. Embryos at E11.5 were removed under sterile conditions. The spinal cord was isolated as described above and positioned into $300 \mu \mathrm{l}$ of $\mathrm{Ma}$ trigel (BD, Le Pont de Claix, France) diluted 1:4 with culture medium. Opened spinal cords were maintained for $2-8 \mathrm{~d}$ in culture (DIC) at $37^{\circ} \mathrm{C}$ in a $6-8 \% \mathrm{CO}_{2}$ incubator with a $100 \%$ humidity atmosphere in the following culture medium: 50\% DMEM (Sigma, St. Louis, MO) containing $25 \mathrm{~mm}$ glucose, 25\% HBSS (Sigma), $15 \%$ distilled water, and $10 \%$ horse serum (Sigma), to which $0.002 \% \mathrm{H}_{2} \mathrm{O}_{2}, \quad 0.03 \%$ L-glutamine (Poly-Labo, Strasbourg, France), and $0.03 \%$ penicillin-streptomycin $(10,000$ $\mathrm{U} / 10,000 \mu \mathrm{g}$; Sigma) were added immediately before use.

Pharmacology. To evaluate the role of 5-HT in the maturation of the GABAergic population in the spinal cord, we either removed all endogenous 5-HT sources by using p-chlorophenylalanine (pCPA; $10 \mu \mathrm{M}$; Sigma), an inhibitor of the enzyme tryptophan hydroxylase (Koe and Weissman, 1966), or added exogenous 5-HT ( $5 \mu \mathrm{M}$; Sigma) directly diluted in the culture medium. 5-HT receptors were selectively antagonized using $5 \mu \mathrm{M}$ of the following pharmacological agents: WAY $100635\left(5-\mathrm{HT}_{1 \mathrm{~A}}\right.$ antagonist; a generous gift from Dr. L. Segu, Université Bordeaux 1, Talence, France), SB 224289 hydrochloride (5- $\mathrm{HT}_{1 \mathrm{~B}}$ antagonist; Tocris, Bristol, UK), ketanserin tartrate salt (5$\mathrm{HT}_{2 \mathrm{~A} / 2 \mathrm{~B}}$ antagonist; Sigma), and 3-tropanylindole-3-carboxylate methiodide $\left(5-\mathrm{HT}_{3}\right.$ receptor antagonist; Sigma). These highly selective antagonists were diluted in the culture medium and renewed every $2 \mathrm{~d}$, as was 5 -HT.

Immunofluorescence. Acute or organotypically cultured spinal cords were fixed in $2 \%$ paraformaldehyde and $10 \%$ sucrose in $0.2 \mathrm{M} \mathrm{PBS}, \mathrm{pH}$ 7.5 , for $2 \mathrm{~h}$ at room temperature. Spinal cords were then rinsed with PBS and incubated in primary antibody for $48 \mathrm{~h}$ at $4^{\circ} \mathrm{C}$ in $0.2 \mathrm{M}$ PBS containing $0.2 \%$ bovine serum albumin (BSA) and $0.1 \%$ Triton $\mathrm{X}-100$. The primary antibodies used in the present study were as follows: rabbit polyclonal anti-GABA (A2052; 1:200; Sigma), rabbit polyclonal anti5-HT (for specificity, see Tramu et al., 1983) (1:5000; kindly provided by Prof. G. Tramu, Université Bordeaux 1, Talence, France), mouse monoclonal anti-NeuN (neuronal nuclei; 1:500; Chemicon, Temecula, CA), and mouse monoclonal anti-microtubule-associated protein $1 \mathrm{~B}$ in a specific phosphorylated form (MAP1B-P; 1:150; a generous gift from Dr. F. Nothias, 'Université Pierre et Marie Curie, Paris, France). After rinsing, spinal cords were incubated at room temperature for $2 \mathrm{~h}$ in a fluoresceinconjugated anti-rabbit IgG (1:100; Sigma) and/or rhodamineconjugated anti-mouse IgG (1:100; Jackson ImmunoResearch, West Grove, PA). After three $10 \mathrm{~min}$ rinses, the preparations were mounted in a mixture containing $90 \%$ glycerol and $10 \%$ PBS, with the addition of $2.5 \%$ 1,4-diazabicyclo[2,2,2] octane (DABCO; Sigma) to reduce the rate of fluorescence quenching. Because we used paraformaldehyde as fixative whereas the GABA-BSA antigene (Sigma) used to immunize rabbits was generated using glutaraldehyde as fixative, we performed control experiments to verify the specificity of our GABA labeling. We tested three times, on lumbar spinal cord sections from E12.5, E13.5, and E14.5 embryos, gradual increases in concentrations $(4,40$, and $400 \mu \mathrm{M})$ of the GABA-glutaraldehyde-BSA conjugate to preabsorb the GABA antiserum. No GABA labeling was observed using $\geq 40 \mu \mathrm{m}$ concentrations of conjugate (Fig. 1A1-A3).

Confocal acquisitions. Preparations were viewed with a BX51 Olympus (Tokyo, Japan) Fluoview 500 confocal microscope equipped with an argon laser light source. For the quantitative analysis, serial optical sections at intervals of $3 \mu \mathrm{m}$ were imaged with a $60 \times$ oil objective. For double labeling, $0.2 \mu \mathrm{m}$ serial optical sections were imaged. Unless stated 
otherwise, images presented here are stacked projections of 15-30 optical sections.

Image analysis and quantification. The distribution of GABA immunoreactivity was analyzed in the ventral gray matter along the entire spinal cord, allowing the establishment of a rostrocaudal cartography of this distribution. To identify the cellular category to which the GABAimmunoreactive (-IR) cell bodies belong, we performed, in eight organotypic cultures, a double staining using the neuronal marker NeuN and the GABA antiserum. In all experiments, GABA-IR somata were immunoreactive for NeuN. These data, which were quantified in three cultures (one at 4 DIC and two at 6 DIC), indicated that $97.7 \%$ of the GABA-IR somata (386 of 395 cell bodies) at 4 DIC and $98.7 \%$ of the GABA-IR somata (146 of 148 cell bodies) at 6 DIC were NeuN positive (Fig. 1 B1$B 3)$. In our quantitative analysis, we paid attention to consider only GABA-IR cell bodies. Also, we systematically checked, on serial confocal sections, for the presence of the nucleus and not considered extensions of the dendritic and axonal arborization of the cell. Quantitative analysis was then performed at the brachial and lumbar levels: series of optical sections were taken at each level in an area chosen at random. The physical dissector technique (Coggeshall and Lekan, 1996) was used to determine the density of GABAergic cells. We used two 3- $\mu$ m-thick optical sections: a reference section (n section) located $10 \mu \mathrm{m}$ below the periependymar layer and a look-up section at the $n+2$ level, the gap between the two sections being determined by the average GABA-IR cell diameter $(5 \mu \mathrm{m})$. Only GABA-IR cells located on the reference section were counted, and those observed on both sections (reference and lookup) were not counted. Thus, the probability of counting the same cell twice was very low. To convert the number of GABA-IR cells counted to a density, we used an optical section area $a_{\text {Ref }}$ of $200 \times 200 \mu \mathrm{m}$, a height of dissector $h_{\text {Dis }}$ of $9 \mu \mathrm{m}$, and a volume of the dissector of $V_{\text {dis }}=a_{\text {Ref }} \times$ $h_{\text {Dis }}$ and calculated the density $N_{\mathrm{v}}$ by dividing the number of GABA-IR cells by $V_{\text {dis. }}$.

Statistics. Quantitative data were presented in histograms in which each bar corresponds to the average of six values from six embryos from three different litters. All values were expressed as mean \pm SEM. Statistical significance of difference was assessed by a paired two-tailed Student's $t$ test or by a nonparametric Kruskal-Wallis one-way ANOVA, followed by a pairwise multiple comparisons post hoc test (Dunn's method) using SigmaStat. The level of significance was set at $p<0.05$.

\section{Results}

\section{The GABAergic population of the spinal ventral gray matter matures according to a rostrocaudal delay in utero and in organotypic culture}

The development of the GABAergic population was studied initially in whole-mount preparations of the acute spinal cord. This study was undertaken to examine the in utero development of the GABAergic population and to enable a subsequent comparison with its development in organotypic culture to determine the validity of the culture model. At the brachial level, GABAergic cells were already present in utero at E11.5 (Fig. $2 \mathrm{~A}$, arrowheads). GABA staining increased markedly at E13.5 when a large number of labeled somata and processes were observed (Fig. 2C, arrowheads and arrow, respectively). Later in embryonic development (E15.5), although GABA-IR cells were still present and their immunoreactivity was strong, the number of stained perikarya seemed to decrease (Fig. 2E). This was confirmed by a quantitative analysis (Fig. $2 G$, black bars) that revealed that the density of GABA-IR somata was very low at E11.5 $\left(3.4 \pm 2.2 \times 10^{3}\right.$ cells/ $\left.\mathrm{mm}^{3}\right)$, reached a peak at E13.5 $\left(47.9 \pm 3.9 \times 10^{3}\right.$ cells $\left./ \mathrm{mm}^{3}\right)$, decreased at E15.5 $\left(19.4 \pm 10.5 \times 10^{3}\right.$ cells $\left./ \mathrm{mm}^{3}\right)$, and remained low until P0. At the lumbar level, GABA immunoreactivity was never detected at E11.5 (Fig. 2B). The first stained somata appeared at E13.5 (Fig. 2D, arrowheads). At E15.5 stage, the number of stained perikarya raised and a large number of processes were immunoreactive for GABA (Fig. $2 F$, arrows). A quantifica- tion of the ontogeny of the GABAergic population at the lumbar level is illustrated in Figure $2 G$ (gray bars). Whereas there was no staining at E11.5, the density of GABA-IR somata increased dramatically from E13.5 $\left(36.1 \pm 9.0 \times 10^{3}\right.$ cells $\left./ \mathrm{mm}^{3}\right)$ to E15.5 $\left(53.4 \pm 12.7 \times 10^{3}\right.$ cells $\left./ \mathrm{mm}^{3}\right)$ when it reached its maximum and then diminished at later stages of development. A statistical analysis indicated that the density of GABA-IR somata at the brachial level was the highest at E13.5 ( $p<0.05$; Dunn's test) compared with E11.5, whereas the following stages (E15.5 to P0) exhibited no differences compared with E11.5. At the lumbar level, although there was no GABA-IR expression at E11.5, the only stage of development that appeared significantly different to E11.5 was E15.5 ( $p<0.05$; Dunn's test), suggesting a peak of GABA immunoreactivity at E15.5. These data indicate that, during the course of embryogenesis in utero, the development of the mouse spinal ventral GABAergic population exhibits two major features: (1) a peak in the density of GABAergic cells is detected at both the brachial and the lumbar levels and (2) a rostrocaudal delay in the expression of this peak in density is present between the brachial and lumbar levels (peak at E13.5 and E15.5, respectively).

To verify whether this ontogenetic pattern is preserved in organotypic culture of the entire spinal cord, we performed a similar immunocytochemical analysis on cultured spinal cords. Spinal cords were taken from E11.5 embryos and maintained in culture. The development of GABA immunoreactivity was then analyzed after 2, 4, 6, and 8 DIC at both the brachial and lumbar levels. At the brachial level, the number of GABA-IR cells increased after 2 DIC, with numerous somata and processes labeled (Fig. $2 \mathrm{H}$, arrowhead and arrow, respectively), and decreased at 6 DIC (Fig. $2 J$ ). These changes were confirmed by quantitative analysis (Fig. $2 L$, black bars) indicating that the density of somata immunoreactive for GABA reached a peak after 2 DIC (68.3 \pm $22.3 \times 10^{3}$ cells $\left./ \mathrm{mm}^{3}\right)$, decreased at 4 DIC $\left(27.6 \pm 8.1 \times 10^{3}\right.$ cells $/ \mathrm{mm}^{3}$ ), and remained low at the subsequent days in culture (6-8 DIC). The statistical analysis revealed that the first stage of maturation in culture that was significantly different from E11.5 was at 2 DIC ( $p<0.05$; Dunn's test). At the lumbar level, GABA-IR somata and processes were present after 2 DIC (Fig. $2 I$ ) at a low density $\left(19.8 \pm 6.0 \times 10^{3}\right.$ cells $\left./ \mathrm{mm}^{3}\right)($ Fig. $2 \mathrm{~L}$, gray bars) compared with the brachial level $\left(68.3 \times 10^{3}\right.$ cells $\left./ \mathrm{mm}^{3}\right)$ (Fig. $2 L$, black bars). Interestingly, after 6 DIC, the density reached its maximum $\left(63.8 \pm 10.9 \times 10^{3}\right.$ cells $\left./ \mathrm{mm}^{3}\right)$ and then slightly decreased at 8 DIC $\left(38.8 \pm 10.3 \times 10^{3}\right.$ cells $\left./ \mathrm{mm}^{3}\right)$. Again, the first stage of maturation in culture that was significantly different from E11.5 was at 6 DIC ( $p<0.05$; Dunn's test). Together, these results indicate that the ontogenic changes in the GABAergic population share similar features in utero and in organotypic culture (i.e., a rostrocaudal delay of maturation of the GABAergic population is observed between upper and lower spinal levels in both conditions).

\section{Development of 5-HT supraspinal inputs in organotypic culture}

In utero, 5-HT supraspinal inputs progressively invade the mouse spinal cord: at E13.5, 5-HT-stained axons are detected only at brachial levels, whereas at E15.5, they have reached lumbar levels (Ballion et al., 2002). Interestingly, the developmental stage at which serotonergic fibers arrive at the respective levels coincides with the period in which the peak of GABA immunoreactivity is detected (present data; Allain et al., 2004b). To check whether the bulbo-spinal 5-HT innervations follow a similar pattern of development in organotypic culture, we performed an immunohistochemical study of the 5-HT system in culture. 


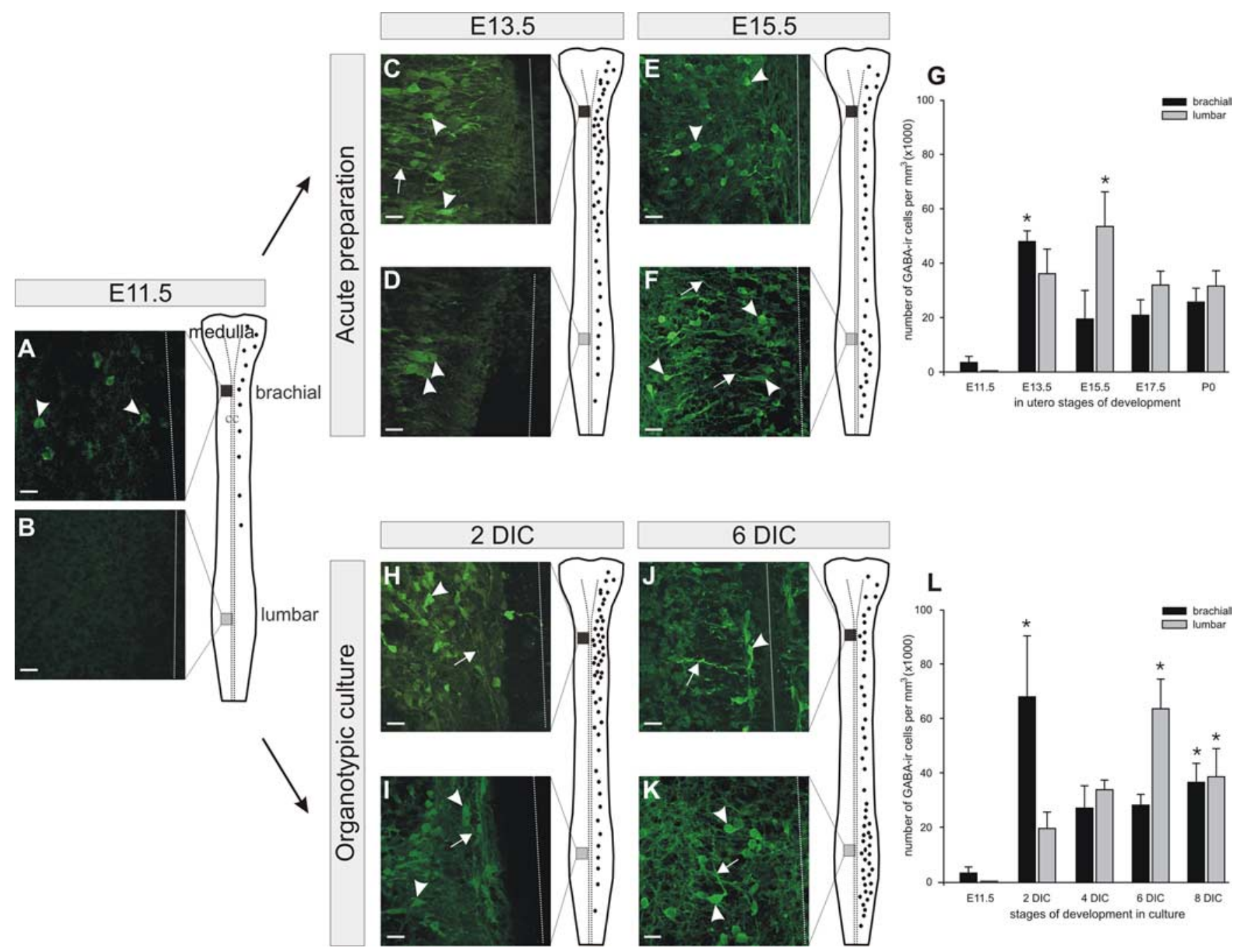

Figure 2. Comparable maturation of the typical GABAergic population in utero $(\boldsymbol{A}-\boldsymbol{G})$ and in organotypic culture $(\boldsymbol{H}-\boldsymbol{L}) \cdot \boldsymbol{A}, \boldsymbol{B}, \mathrm{At}$ E11.5, sparse GABA immunoreactivity is first detected at brachial levels $(\boldsymbol{A})$, whereas no GABA labeling is present at lumbar levels $(\boldsymbol{B}) . \boldsymbol{C}, \boldsymbol{D}$, AtE13.5, numerous cells are detected at brachial levels, whereas few stained cells are revealed at lumbar levels. $\boldsymbol{E}, \boldsymbol{F}$, At $\mathrm{E} 15.5$, the reverse pattern is observed in the spinal cord with a low number of GABA-IR cells at brachial levels $(\boldsymbol{E})$ and a high number of GABA-IR cells at lumbar levels $(\boldsymbol{F}) . \boldsymbol{G}$, The quantitative analysis reveals peaks (asterisks) of GABA-IR density at E13.5 and at E15.5, at the brachial level (black bars) and at the lumbar level (gray bars), respectively ( ${ }^{*} p<0.05$; Dunn's test), compared with E11.5. $\boldsymbol{H}, \boldsymbol{I}$, In organotypic culture after 2 DIC, numerous GABA-IR cells are detected at the brachial level $(\boldsymbol{H})$, whereas the immunoreactivity is less apparent at the lumbar level $(\boldsymbol{I})$. $\boldsymbol{J}, \boldsymbol{K}$, After $6 \mathrm{DIC}$, fewer GABA somata are present at the brachial level, whereas a denser population of GABA-IR cells is present at the lumbar level. $L$, Quantification of the number of GABA-IR cells indicates a peak (asterisks) at $2 \mathrm{DIC}$ at the brachial level and at $6 \mathrm{DIC}$ at the lumbar level ( ${ }^{*} p<0.05$; Dunn's test; compared with E11.5). The arrows indicate the GABA-IR process, and arrowheads indicate GABA-IR soma. $n=6$ for each stage of development. Scale bars, $20 \mu \mathrm{m}$.

At E11.5, the serotonergic raphe nuclei detected in the medulla (Ballion et al., 2002) did not have projections to the brachial levels of the spinal cord (data not shown). After 2 DIC, 5-HT-IR somata were found in the medulla (Fig. 3A1, arrowheads), but the 5-HT immunoreactivity was no longer confined to the somata because 5-HT-IR processes were clearly labeled (Fig. 3A1, arrows). This pattern of expression was maintained during the subsequent days in culture [4 DIC (Fig. 3A2), 6 DIC (Fig. 3A3), and 8 DIC (Fig. 3A4)]. At 2 DIC, the first serotonergic fibers were detected at the brachial level (Fig. 3A5). After 4 DIC, fibers immunoreactive for 5-HT reached the thoracic level (Fig. 3A6). These fibers exhibited growth cones as seen in Figure 3B4-B6. Using anti-MAP1B-P, the phosphorylated isoform of MAP1B that is enriched in the more distal portion of growing axons (Black et al., 1994), we found, in the spinal thoracic level as well as in the medulla (Fig. 3B), that 5-HT immunoreactivity was always associated with MAP1B-P immunoreactivity, indicating that 5-HT labeling was restricted to growing axons and was present in growth cones. Subsequently, growing 5-HT axons were detected at lower thoracic levels at 6 DIC (Fig. 3A7). These fibers exhibited growth cones (Fig. 3A9, arrows). At 8 DIC, growing axons were detected at thoracic and lumbar levels (Fig. 3A8,A10). These data indicate that the development of spinal 5-HT projections in organotypic culture parallels that in utero. In organotypic preparations, however, this maturation seems to occur, at least at the lumbar level, with a 2 to $4 \mathrm{~d}$ delay relative to in vivo maturation: at E15.5 in utero (Ballion et al., 2002) and at E11.5 plus 6-8 DIC in organotypic culture.

\section{Role of 5-HT in the maturation of the GABAergic cell population}

We have shown that the overall maturation of the spinal GABAergic cell population and 5-HT descending inputs is comparable in organotypic preparations and during in utero development. Our results from organotypic cultures indicate that 5-HT descending inputs reach brachial and lumbar levels after 2-4 and 

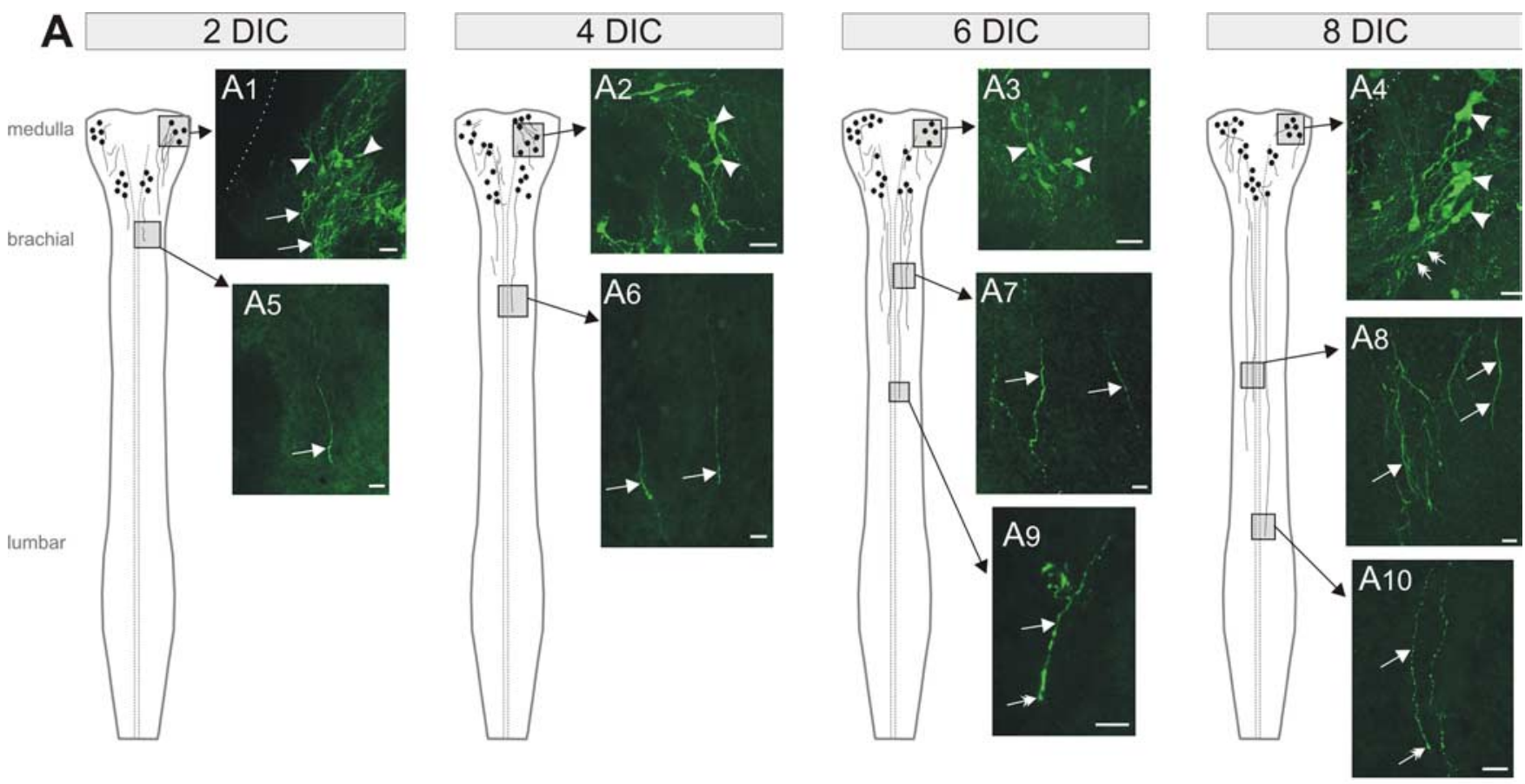

B
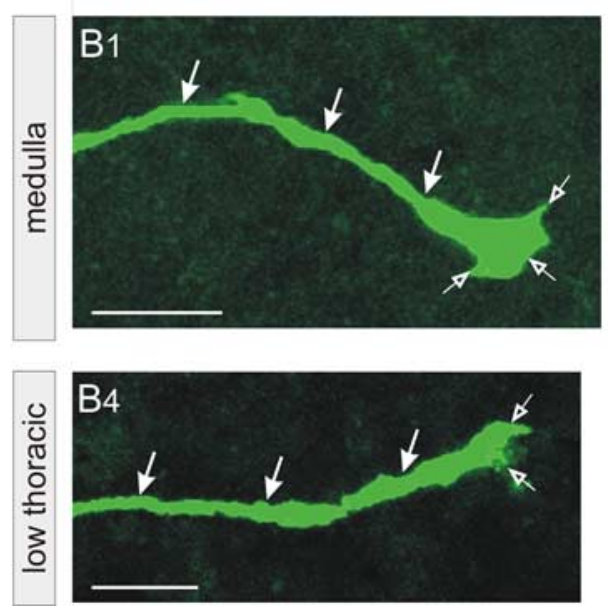
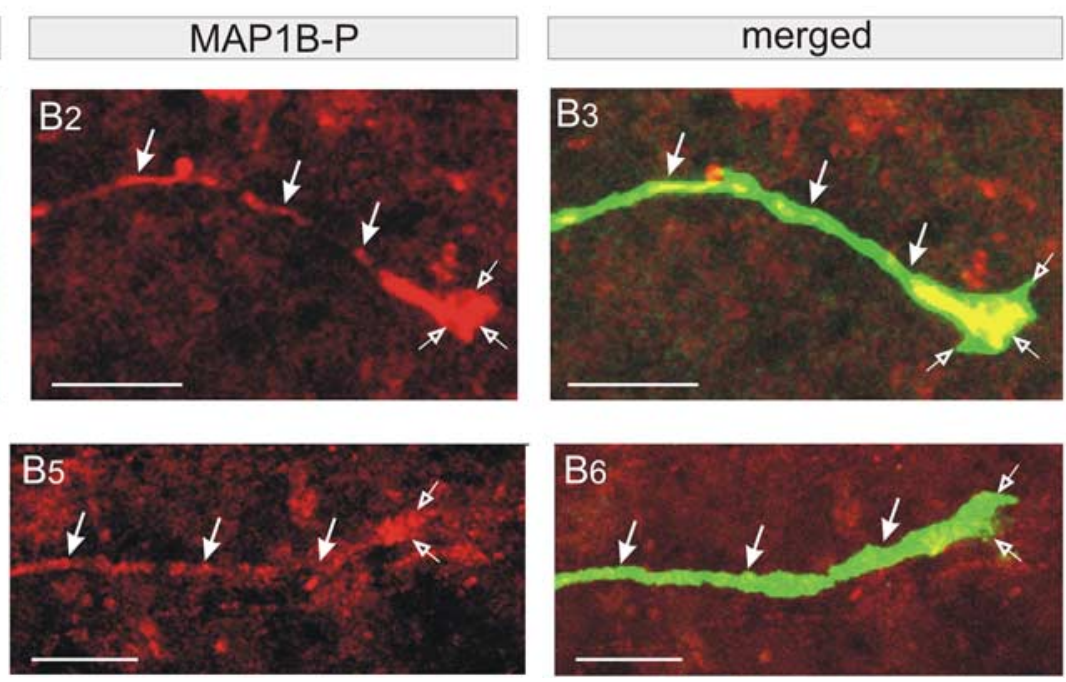

Figure 3. Maturation of 5 -HT descending inputs in organotypic culture $(\boldsymbol{A})$ and double 5 -HT/MAP1B-P labeling $(\boldsymbol{B})$. $\boldsymbol{A} 1-\boldsymbol{A} 4$, The raphe nuclei express 5 -HT-IR cells and processes in the medulla during the entire course of the culture. $A 5$, After $2 \mathrm{DIC}$, starting at E11.5, 5 -HT descending inputs are found only at the brachial level. $A 6-A 10$, Descending fibers progressively invade the spinal cord to reach lumbar levels after $8 \mathrm{DIC}(\boldsymbol{A} \mathbf{1 0}) . n=4$ at each stage. $\boldsymbol{B 1}-\boldsymbol{B} 4,5$-HT-IR fiber (green, arrows) in the medulla (B1) in the low thoracic level (B4) exhibiting a growth cone (open arrows). $\boldsymbol{B 2}-\boldsymbol{B 5}$, MAP1B-P labeling in the same fiber (red, arrows). Note that the growth cone is MAP1B-P positive (open arrows). B3-B6, Merged image showing the superposition of the 5-HT and MAP1B-P labeling (yellow). The images shown in $\boldsymbol{B} \mathbf{1}-\boldsymbol{B} \boldsymbol{6}$ are $0.2 \mu \mathrm{m}$ confocal sections. Scale bars: $\boldsymbol{A}, 20 \mu \mathrm{m} ; \boldsymbol{B}, 10 \mu \mathrm{m}$.

$6-8 \mathrm{~d}$, respectively (Fig. $3 A$ ), and that this timing coincides with marked changes in the GABAergic cell population. Therefore, to understand the potential role of 5-HT descending inputs in the maturation of the GABAergic population, we manipulated the expression of 5-HT in organotypic preparations. This was done in three ways. In a first set of experiments, the ontogeny of GABA immunoreactivity was followed in the spinal cord in the absence of all 5-HT sources [without the medulla, thus suppressing raphe nuclei projections, and in the presence of $\mathrm{PCPA}$ to prevent the release of 5-HT from ectopic 5-HT intraspinal neurons, as described by Branchereau et al. (2002)] (see schematic drawing in Fig. 4A). Using the same immunocytochemical procedure as described above, we followed the evolution of the GABAergic pop- ulation from 2 to 8 DIC. As in control culture, a high number of GABAergic cells (Fig. $4 B$, arrowheads) with stained processes (arrow) was found at the brachial level after 2 DIC. After 6 DIC, the number of stained cells decreased (Fig. 4C). A similar pattern of GABA immunoreactivity was detected at lumbar levels (data not shown), indicating that GABA-IR cells were uniformly distributed along the longitudinal axis of the cord, as illustrated in Figure $4 D$. A quantitative analysis of the GABA staining indicated that although there was still a peak in the density of the GABA-IR cells at 4 DIC at the brachial level and 2-4 DIC at the lumbar level (first stages significantly different from E11.5; $p<0.05$; Dunn's test; $70.6 \pm 21.4 \times 10^{3}$ cells $/ \mathrm{mm}^{3}$ for the brachial level and $47.0 \pm 13.7 \times 10^{3}$ cells $/ \mathrm{mm}^{3}$ for the lumbar level), the rostro- 


\section{DIC}
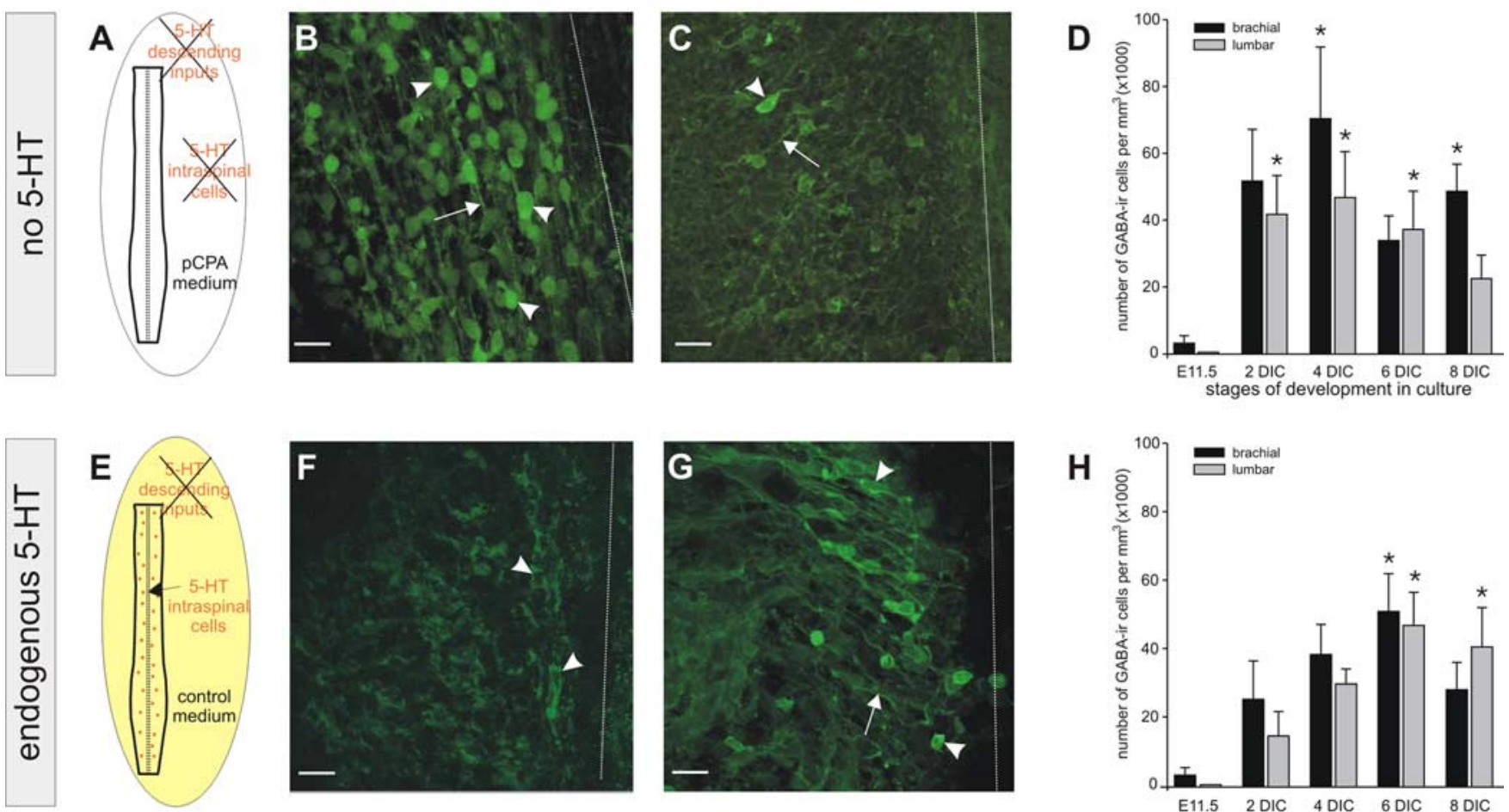

H
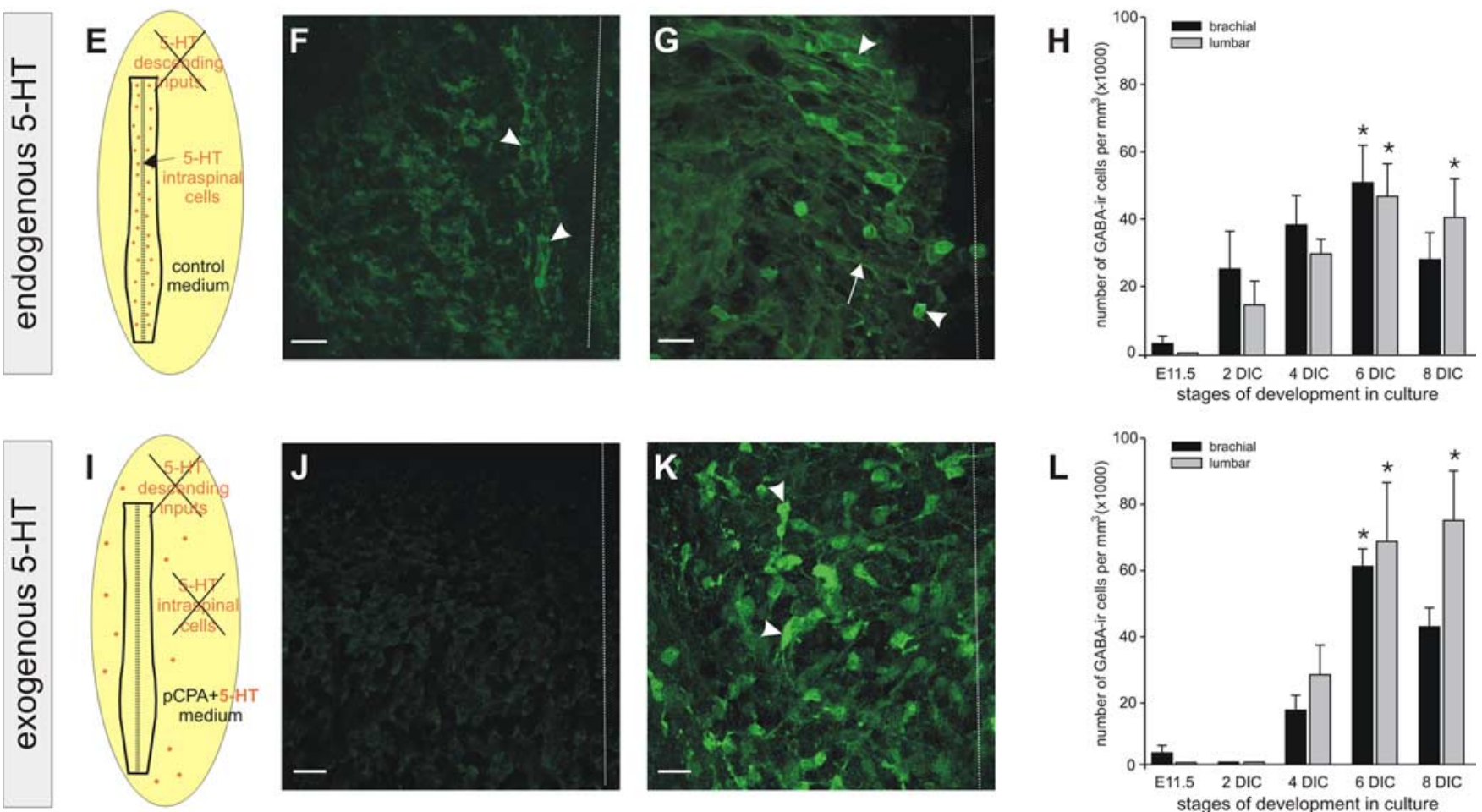

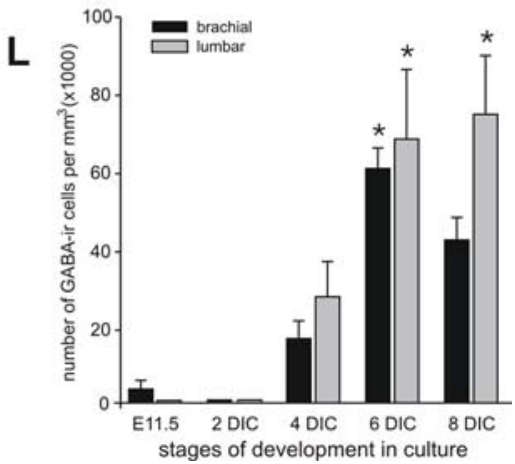

Figure 4. Role of 5-HT on the maturation of the GABAergic spinal population. $A$, Schematic drawing of the spinal cord without the medulla maintained in culture with pCPA to eliminate 5 -HT synthesis. $\boldsymbol{B}, \boldsymbol{C}$, In the absence of $5-\mathrm{HT}$, a very high number of cells is immunostained for GABA at $2 \mathrm{DIC}$, as illustrated at the brachial level (B); this number then decreases after $6 \mathrm{DIC}(\boldsymbol{C})$. $\boldsymbol{D}, \mathbf{Q u a n t i t a t i v e}$ analyses reveal a synchronized expression of GABA-IR cells between the brachial and lumbar levels and a peak in density at 2 DIC (asterisks) at the brachial level and at 4 DIC at the lumbar level (asterisks). $\boldsymbol{E}$, Organotypic cultures without the medulla containing ectopic 5-HT intraspinal cells (Branchereau et al., 2002). $\boldsymbol{F}$, After 2 DIC, few GABA-IR cells are detected at the brachial level. G, The number of immunoreactive cells increases after 6 DIC. $\boldsymbol{H}$, Note that the peak of maximum density is synchronized at both levels studied and emerges after 6 DIC (first asterisks). $\boldsymbol{I}$, The addition of 5 -HT to the medium in the presence of pCPA provides an exogenous source of 5 -HT to the preparation. $\boldsymbol{J}, \boldsymbol{K}$, No staining is detected at $2 \mathrm{DIC}$ at the brachial level $(\boldsymbol{J})$, whereas numerous GABA-IR cells are observed at $6 \mathrm{DIC}$ at the same level $(\boldsymbol{K})$. $\boldsymbol{L}$, The development of the GABAergic population is synchronized at the brachial and lumbar levels and exhibits a peak of immunoreactivity at 6 DIC (first asterisks). To make a direct comparison, all pictures were taken at the brachial level. ${ }^{*} p<0.05$ (Dunn's posthoc test) compared with E11.5. The arrows indicate GABA-IRneurites, and the arrowheads indicate GABA-IR soma. The dotted lines indicate the midline. $n=6$ for each stage in each bar.

caudal delay between brachial and lumbar levels had disappeared at the considered stages of culture development (Fig. 4D). At later stages of development, the density of GABAergic cells decreased at both levels of the spinal cord (after 8 DIC, $48.9 \pm 8.1 \times$ $10^{3}$ cells $/ \mathrm{mm}^{3}$ at the brachial level and $22.8 \pm 7.0 \times 10^{3}$ cells/ $\mathrm{mm}^{3}$ at the lumbar level). This result indicates that descending information is necessary for the rostrocaudal delay of the transient increase in the density of the GABA-IR cell population. Moreover, compared with the development in the presence of descending inputs, the maximum density of GABAergic cells is detected earlier at lumbar levels in the absence of descending inputs and when the 5-HT synthesis is blocked: 2-4 DIC in the absence of descending inputs plus pCPA (Fig. $4 D$, gray bar) and
6 DIC in the presence of descending inputs (Fig. $2 L$, gray bar). However, this early maturation is not present at brachial levels: peak density at 2 DIC with descending inputs (Fig. $2 L$, black bar) and at 4 DIC without descending inputs (Fig. $4 D$, black bar).

In a second set of experiments, to better understand the role of $5-\mathrm{HT}$, the medulla was removed to prevent the growth of descending axons, but pCPA was not applied, thus allowing 5-HT synthesis by ectopic cells (endogenous 5-HT) (Fig. 4E). Under these conditions, in contrast to previous results, only sparse GABA-IR cells were observed at the brachial level after 2 DIC (Fig. $4 F$, arrowheads). At 6 DIC, the number of GABA-IR cells was higher (Fig. $4 G$ ), with a similar pattern of expression along the length of the entire spinal cord (data not shown). As illus- 
trated in Figure $4 H$, the rostrocaudal delay was not present, and the peaks of GABA cell density occurred at 6 DIC (first stage significantly different from E11.5; $p<0.05$; Dunn's test) at both the brachial and lumbar levels $\left(51.3 \pm 11 \times 10^{3}\right.$ and $47.2 \pm 9.6 \times$ $10^{3}$ cells $/ \mathrm{mm}^{3}$ at the brachial and lumbar levels, respectively).

In a third set of experiments, exogenous 5-HT was applied chronically during the maturation of the cultured spinal cord without the medulla and in the presence of pCPA (exogenous 5-HT) (Fig. 4I). Under these conditions, we found that after 2 DIC there was no GABA labeling in the entire spinal cord (Fig. $4 \mathrm{~J})$. However, at $6 \mathrm{DIC}$, a dense cell population immunoreactive for GABA was present (Fig. $4 K$ ). This delay in the appearance of the GABA system was uniform along the spinal cord (data not shown). A quantitative analysis (Fig. $4 L$ ) showed that in the presence of a chronic application of 5-HT in the culture medium, the ontogeny of the GABA-IR cell population follows, at the considered stage of culture development, concomitant changes at both the brachial and lumbar levels and that the peaks of maximum GABA density are delayed compared with cultures not treated with 5-HT (Fig. 4, compare $D, L$ ): the first stage significantly different from E11.5 was 6 DIC at both levels $(p<0.05$; Dunn's test). This result indicates that, although not necessary for the expression of the spinal GABA cells, 5-HT postpones the time window of maximum GABA expression.

Together, these three sets of experiments revealed that at the considered stages of development, in the absence of the medulla, there was an apparent synchronized maturation of the GABA phenotype along the rostrocaudal axis. This result surprised us considering the intraspinal rostrocaudal gradient of neurogenesis. Also, to control whether this gradient was affecting the maturation of the GABA phenotype at early stages of culture development, we analyzed the GABA phenotype after 1 and 2 DIC (i.e., on the day-to-day basis instead on every $2 \mathrm{~d}$ ) in organotypic cultures developing in the absence of the medulla and 5-HT. At 1 DIC, we found a significantly higher density of GABA-IR somata at brachial level $\left(32.6 \pm 2.9 \times 10^{3}\right.$ cells $\left./ \mathrm{mm}^{3}\right)$ than at the lumbar level $\left(17.3 \pm 5.7 \times 10^{3}\right.$ cells $\left./ \mathrm{mm}^{3}\right)(p<0.05$; Student's $t$ test; $n=$ 6 cultures), indicating that the rostrocaudal gradient of neurogenesis accounts for the development of GABA-IR neurons along the spinal cord. At 2 DIC, no significant differences in the density of GABA-IR somata were observed between the brachial level $\left(40.2 \pm 8.7 \times 10^{3}\right.$ cells $\left./ \mathrm{mm}^{3}\right)$ and the lumbar level $(37.6 \pm 6.8 \times$ $10^{3}$ cells $\left./ \mathrm{mm}^{3}\right)(n=12$ cultures; data not shown $)$.

\section{5-HT1 receptor family is involved in the control by 5-HT of GABAergic expression}

To identify which type of 5-HT receptor mediates the effects of exogenous application of 5-HT described above, we selectively blocked the different types of 5-HT receptors known to be present in ventral parts of the spinal cord (Verge and Calas, 2000) and analyzed GABA expression at the brachial level in spinal cords maintained 4 DIC without the medulla. At this stage of development in culture, the difference in the expression of the GABAergic density without 5-HT (pCPA medium) and with 5-HT (pCPA plus 5-HT medium) is at its largest (Fig. 4, compare $D, L$, black bars at 4 DIC, and Fig. 5, between control and 5-HT). The addition of the $5-\mathrm{HT}_{1 \mathrm{~A}}$ receptor antagonist (Fig. 5, WAY) to the 5-HT medium prevents the decrease in the density of GABA-IR cells $(p<0.05$; Dunn's test between +WAY and 5-HT). Similarly, chronic application of the $5-\mathrm{HT}_{1 \mathrm{~B}}$ receptor antagonist (Fig. 5, SB) prevents the reduction of the density of GABAergic cells ( $p<0.05$; Dunn's test between + SB and 5-HT). In contrast, neither the $5-\mathrm{HT}_{2 \mathrm{~A} / 2 \mathrm{C}}$ receptor antagonist (Fig. 5, ketanserin) nor the 5- $\mathrm{HT}_{3}$ receptor antagonist (Fig. 5, 3-TI-3$\mathrm{CM}$ ) prevented the inhibiting 5-HT action on the maturation of the GABAergic population at 4 DIC. This pharmacological demonstration indicates that 5-HT exerts its downregulating effect on the GABAergic population through the $5-\mathrm{HT}_{1}$ receptor family.

\section{Role of 5-HT descending inputs on the maturation of the GABAergic population}

In light of our results, indicating that 5-HT controls the expression of the GABAergic intraspinal population during embryonic development, it is important to know whether 5-HT fibers play the key role in this ontogenic phenomenon or whether other phenomenon may also be involved. To test this hypothesis, organotypic cultures of embryonic spinal cords with the medulla intact and with pCPA in the culture medium were prepared to examine the effects of selectively blocking of 5-HT synthesis while leaving other descending systems unchanged (Fig. 6). Under such experimental conditions, the maturation of the GABAergic population, both at brachial and lumbar levels, expressed a similar pattern of development to that observed when neither the medulla nor 5 -HT is present (compare Figs. $4 D, 6 D$ ). Indeed, the peak of GABA-IR cell density was detected at 2 DIC (first stage of culture development statistically different from E11.5; $p<0.05$; Dunn's test; $65.9 \pm 17.5 \times 10^{3}$ cells $/ \mathrm{mm}^{3}$ and $98.0 \pm 5.3 \times 10^{3}$ cells $/ \mathrm{mm}^{3}$ at the brachial and lumbar levels, respectively) and followed by a substantial decrease from 4 to 8 DIC. These data mean that, in the absence of 5-HT because of the blockage of its synthesis in the raphe nuclei, the development of the GABAergic population appears synchronous along the spinal cord at the examined stages of culture development. Hence, the 5-HT system seems to be solely responsible for the rostrocaudal delay in development of the GABAergic population. If we compare the maturation of the GABA cells in the presence or absence of descending

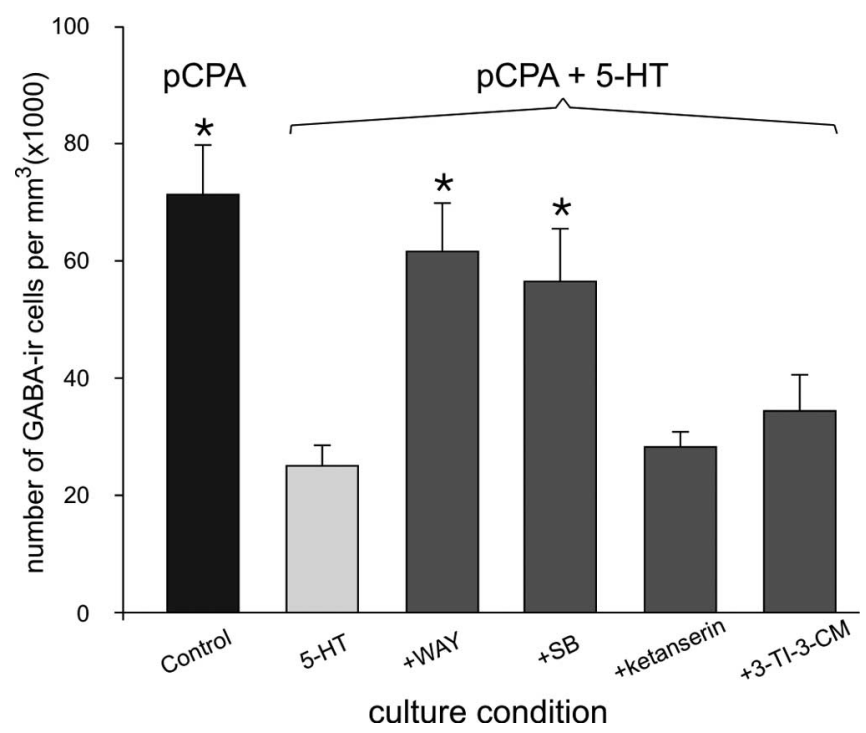

Figure 5. Implication of the $5-\mathrm{HT}_{1}$ receptor family in the downregulating effect of 5-HT on the maturation of the GABAergic cell population. Organotypic preparations were maintained for 4 DIC without the medulla and in the presence of pCPA, and the density of GABA-IR cells was then quantified at the brachial level. As illustrated in Figure 3D, a high number of GABA-IR cells is observed in the control condition (PCPA; black bar). The addition of 5-HT to the medium, however, decreases the density of GABA-labeled cells (light gray bar). In the presence of the $5-\mathrm{HT}_{1 \mathrm{~A}}$ receptor antagonist (WAY) or $5-\mathrm{HT}_{1 \mathrm{~B}}$ receptor antagonist $(\mathrm{SB})$, the downregulating effect of 5-HT is not observed. In the presence of either the $5-\mathrm{HT}_{2 \mathrm{~A} / 2 \mathrm{C}}$ receptor antagonist (ketanserin) or $5-\mathrm{HT}_{3}$ receptor antagonist (3-TI-3-CM), however, the inhibiting effect is still observed. ${ }^{*} p<0.05$ versus the 5 -HT control (Dunn's post hoc test). 

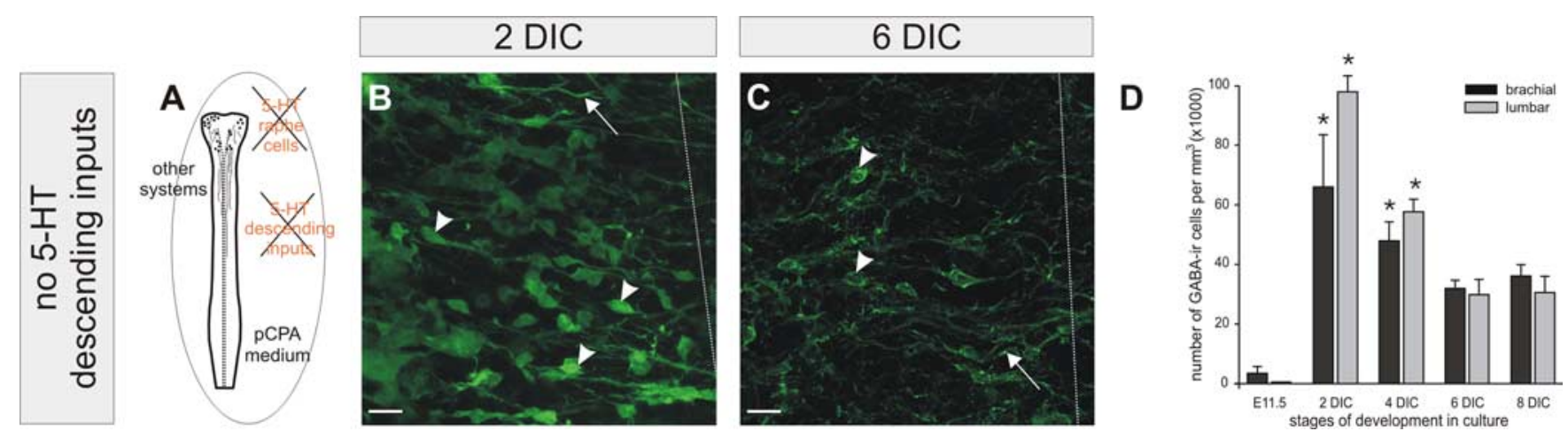

Figure 6. Role of $5-H T$ descending inputs on the maturation of the GABAergic spinal population. $A$, Schematic drawing of the spinal cord and medulla maintained in culture with pCPA to eliminate 5-HT synthesis. $B$, After 2 DIC, numerous cells and processes are stained for GABA at the brachial level. $\boldsymbol{C}$, After 6 DIC, the number of GABA-IR cells has diminished. $D$, The quantification of the evolution in culture of the number of GABA-IR cells indicates that GABA maturation is similar at brachial and lumbar levels, with no rostrocaudal delay and a common peak of GABA cell density at 2 DIC (first asterisks). ${ }^{*} p<0.05$ (Dunn's post hoc test) compared with E11.5. The arrows indicate GABA-IR neurites, and the arrowheads indicate GABA-IR soma. The dotted lines indicate the midline. $n=6$ for each stage of development.

inputs, the maximum density of GABA cell is detected earlier at lumbar levels when descending inputs are absent: 2 DIC in the absence of 5-HT descending inputs (Fig. $6 \mathrm{D}$, gray bar) and $6 \mathrm{DIC}$ in their presence (Fig. $2 L$, gray bar). However, as observed in the absence of all descending inputs (Fig. $4 \mathrm{D}$ ), this earlier maturation is not present at brachial levels: peak of density at 2 DIC with (Fig. $2 L$, black bar) or without (Fig. $6 D$, black bar) 5 -HT descending fibers.

\section{Discussion}

Emergence of inhibitory interneuronal populations is a key step in the construction of functional spinal motor networks. This inhibitory component is dependent on the establishment of intraspinal GABA-IR and glycine-IR interneurons that progressively switch during embryogenesis from an excitatory to inhibitory mode of action. Whereas the mechanisms underlying this switch from excitation to inhibition are well studied, the control of the emergence of GABA and glycine phenotypes is poorly documented. This point is rather important regarding the putative role of GABA itself in the switch from excitation to inhibition (Ganguly et al., 2001; Leitch et al., 2005). Our study demonstrates that the 5-HT supraspinal system controls the emergence of GABA interneurons. We show that (1) the maturation of GABAergic cells is similar in utero and in organotypic cultures (i.e., this population emerges after a rostrocaudal gradient and presents a peak of expression), (2) the peak expression is dependent on the presence of supraspinal 5-HT, and (3) 5-HT exerts a downregulation on the emergence of the GABAergic phenotype via $5-\mathrm{HT}_{1}$ receptors.

\section{Transient expression of GABA}

Our analysis of the ontogeny of GABA cells in the mouse spinal cords maintained in organotypic culture reveals a transient increase in their density, as described in utero (Fig. 2A-G) (Allain et al., 2004b). This increase may be explained by either a transient expression of glutamic acid decarboxylase (GAD) in ventral neurons or a redistribution of the GABA-IR neurons toward more dorsal parts of the spinal cord, possibly accompanied by programmed cell death (Yamamoto and Henderson, 1999). Recent data using organotypic cultures of spinal cord slices support the first hypothesis and indicate that the extinction of GABA labeling in ventral somata may be attributable to a rapid translocation of GAD from cell bodies to synaptic terminals (Phelps et al., 1999; Tran et al., 2003). Considering that we describe a transient in- crease in GABA-IR somata both in utero and in organotypic culture of isolated spinal cords (without modulatory descending inputs), it is probable that intrinsic factors (intraspinal) rather than extrinsic factors (supraspinal or peripheral sources) are involved in the transient expression of GABA. Furthermore, the expression of the GABA phenotype independently of extrinsic factors has also been reported in dissociated cells of the embryonic cortex and cultured dorsal root ganglion neurons (Gotz and Bolz, 1994; Chauvet et al., 1995).

\section{Downregulation of the GABA phenotype by 5-HT}

5-HT promotes the emergence of the GABA phenotype as demonstrated by the graft of embryonic raphe cells in the injured spinal cord (Dumoulin et al., 2000) and by immortalized serotonergic precursors (Eaton et al., 1998). However, our data highlight an opposite role of 5-HT on the GABA phenotype that may be as a result of the embryonic nature of the spinal cords. Indeed, it is likely that 5-HT effects vary according to the developmental stage of the neuronal tissue. Interestingly, differential effects of GABA on the expression of neuropeptide $Y$ have been described during the maturation in vitro of hippocampal interneurons (Marty et al., 1996).

\section{5-HT receptors involved in the transient expression of the GABA phenotype}

5-HT receptors are widely distributed throughout the mammalian CNS (Barnes and Sharp, 1999; Verge and Calas, 2000), few of them being described in the spinal cord (Marlier et al., 1991). In the adult spinal cord, $5-\mathrm{HT}_{1}$ and $5-\mathrm{HT}_{2}$ receptors are involved in (1) the modulation of motor networks (Jackson and White, 1990; Cazalets et al., 1992; Beato and Nistri, 1998), (2) the modulation of motoneuronal excitability (Takahashi and Berger, 1990; Wang and Dun, 1990), and (3) spinal cord recovery (Antri et al., 2003; Norreel et al., 2003). The role of these receptors in the maturation of embryonic networks is poorly understood. Although it has been shown that $5-\mathrm{HT}_{1 \mathrm{~A}}$ receptors are present in rat embryonic brainstem cultures (Hillion et al., 1994), the presence and development of 5- $\mathrm{HT}_{1 \mathrm{~A}}$ and 5- $\mathrm{HT}_{1 \mathrm{~B}}$ receptors has been studied mainly in early postnatal stages in various structures of the CNS, including the spinal cord (Bennett-Clarke et al., 1993; Miquel et al., 1994; Talley et al., 1997). These studies, which demonstrate an early and dynamic expression of $5-\mathrm{HT}_{1 \mathrm{~A}}$ and $5-\mathrm{HT}_{1 \mathrm{~B}}$ receptors, indicate that these receptors are important during development 
(Gaspar et al., 2003). In a previous study, we showed that 5-HT inputs repress the expression of ectopic intraspinal 5-HT cells through $5-\mathrm{HT}_{1 \mathrm{~A}}$ receptors (Branchereau et al., 2002). Our results highlight the role of the 5-HT1 receptors in the negative control by 5 -HT descending inputs of the transient expression of the GABA phenotype; suggesting that $5-\mathrm{HT}_{1 \mathrm{~A}}$ and $5-\mathrm{HT}_{1 \mathrm{~B}}$ receptors are also present in the early stages of mouse embryonic development and play an important role in the emergence of neural networks. Finally, 5-HT exerts its control on the emergence of embryonic spinal neuronal networks through $5-\mathrm{HT}_{1}$ receptors, whereas in postnatal stages, this bio-amine acts prominently on $5-\mathrm{HT}_{2}$ receptors to shape mature spinal motor networks (Norreel et al., 2003).

\section{Spatio-temporal differential effect of 5-HT on GABA phenotype expression} Our in vitro results showing a difference in the time window for the appearance of the GABA-IR peak between brachial and lumbar levels are in agreement with the ones reported in utero (Fig. 2) (Allain et al., 2004b). In addition, our data demonstrate that there is a differential downregulating rostrocaudal (brachial versus lumbar) effect on the GABA phenotype expression because of endogenous 5-HT coming from the descending raphe fibers but not from either the endogenous intraspinal or the exogenously applied 5-HT, as illustrated in the summary diagram (Fig. 7). However, when we compare the maturation of the GABA phenotype in the absence of 5-HT but with (Fig. 7C,D) or without $(E, F)$ the medulla, an upregulating effect on the GABA phenotype occurs. Indeed, when the medulla is present (i.e., other descending inputs are present), the GABA phenotype develops earlier than when the medulla is absent. These data suggest that other inputs from the medulla may speed up the maturation processes. Among possible descending inputs, noradrenergic inputs could be candidate because they invade the spinal cord at early stages (Commissiong, 1983) but not before 5-HT inputs (Rajaofetra et al., 1989; Ballion et al., 2002). Moreover, peptidergic inputs described as colocalized in 5-HT axons must be considered as well as GABA descending inputs that are expressed in 5-HT axons (Hokfelt et al., 2000).

Regulation by 5-HT on the expression of the GABA phenotype might be linked to the maturation of the bulbo-spinal descending inputs controlling the regulation of receptor-dependent cascades and/or to an activity-dependent mechanism. A recent study in the developing spinal cord of Xenopus laevis embryos has demonstrated that suppression or enhancement of spike activity in vivo causes homeostatic changes of the transmitter phenotype (Borodinsky et al., 2004). Spike suppression increases the expression of excitatory transmitters (glutamate, acetylcholine) and decreases the occurrence of inhibitory transmitters (GABA, glycine), whereas spike enhancement has the opposite effect. We have previously shown that 5 -HT acts via an excitatory mode of action on embryonic mouse spinal networks and leads to an enhancement of spike production in motor networks (Branchereau et al., 2000). In a similar way, 5-HT produces a depolarizing effect that affects a higher number of motoneurons between E12 and E18 in the chick spinal cord (Muramoto et al., 1996). Our results do not support the observations of Borodinsky et al. (2004), suggesting an increase in the GABA transmitter phenotype when 5-HT-dependent activity is higher. However, if we assume that early in the development GABA acts as an excitatory transmitter (Branchereau et al., 2002), then the 5-HT downregulating effect on GABA expression becomes relevant.

Our data show that the role of 5-HT in promoting activitydependent phenomenon via its descending inputs is directly related with the timing of arrival of spinal cord-invading terminals. 5-HT inputs invade the lumbar level only after 6-8 DIC (Fig. 3); therefore, they are likely unable to trigger activity at earlier stages. In this context, one can imagine the following developmental mechanisms: (1) the GABAergic cellular population emerges at rostral levels before the arrival of supraspinal 5-HT inputs (Fig. 2A) (Ballion et al., 2002) and (2) this population of GABAergic cells progressively drives the expression of GABA toward caudal levels. Indeed, as reviewed by Lauder et al. (1998), it is known that GABA might play a trophic role, promoting its own pheno- 
type. In the same way, two studies indicate that GABA drives its own developmental switch from excitatory to inhibitory response to GABA (Ganguly et al., 2001; Leitch et al., 2005). Whereas 5-HT descending inputs do not seem to interfere with the establishment of the GABA population at brachial level, they exert a strong downregulation on the expression of this population at the lumbar level. This downregulation of supraspinal 5-HT inputs at caudal levels may be necessary for the delayed establishment of inhibitory inputs in motor networks located at lumbar levels to match the maturation of peripheral targets and the arrival of sensory inputs that start to be functional at birth (Mears and Frank, 1997; Koo and Pfaff, 2002) (for review, see Glover, 2000).

\section{References}

Allain AE, Meyrand P, Branchereau P (2004a) Serotonin slows down the maturation of the GABAergic neuronal population in the mouse spinal cord via 5- $\mathrm{HT}_{1}$ receptor family. FENS Abstr 2:A213.1.

Allain AE, Bairi A, Meyrand P, Branchereau P (2004b) Ontogenic changes of the GABAergic system in the embryonic mouse spinal cord. Brain Res 1000:134-147.

Antri M, Mouffle C, Orsal D, Barthe JY (2003) $5-\mathrm{HT}_{1 \mathrm{~A}}$ receptors are involved in short- and long-term processes responsible for 5-HT-induced locomotor function recovery in chronic spinal rat. Eur J Neurosci 18:1963-1972.

Ballion B, Branchereau P, Chapron J, Viala D (2002) Ontogeny of descending serotonergic innervation and evidence for intraspinal 5-HT neurons in the mouse spinal cord. Dev Brain Res 137:81-88.

Barnes NM, Sharp T (1999) A review of central 5-HT receptors and their function. Neuropharmacology 38:1083-1152.

Beato M, Nistri A (1998) Serotonin-induced inhibition of locomotor rhythm of the rat isolated spinal cord is mediated by the $5-\mathrm{HT}_{1}$ receptor class. Proc R Soc Lond B Biol Sci 265:2073-2080.

Ben-Ari Y (2002) Excitatory actions of GABA during development: the nature of the nurture. Nat Rev Neurosci 3:728-739.

Bennett-Clarke CA, Leslie MJ, Chiaia NL, Rhoades RW (1993) Serotonin 1B receptors in the developing somatosensory and visual cortices are located on thalamocortical axons. Proc Natl Acad Sci USA 90:153-157.

Binor E, Heathcote RD (2001) Development of GABA-immunoreactive neuron patterning in the spinal cord. J Comp Neurol 438:1-11.

Black MM, Slaughter T, Fischer I (1994) Microtubule-associated protein 1b (MAP1b) is concentrated in the distal region of growing axons. J Neurosci 14:857-870.

Borodinsky LN, Root CM, Cronin JA, Sann SB, Gu X, Spitzer NC (2004) Activity-dependent homeostatic specification of transmitter expression in embryonic neurons. Nature 429:523-530.

Branchereau P, Morin D, Bonnot A, Ballion B, Chapron J, Viala D (2000) Development of lumbar rhythmic networks: from embryonic to neonate locomotor-like patterns in the mouse. Brain Res Bull 53:711-718.

Branchereau P, Chapron J, Meyrand P (2002) Descending 5-hydroxytryptamine raphe inputs repress the expression of serotonergic neurons and slow the maturation of inhibitory systems in mouse embryonic spinal cord. J Neurosci 22:2598-2606.

Cazalets J-R, Sqalli-Houssaini Y, Clarac F (1992) Activation of the central pattern generators for locomotion by serotonin and excitatory amino acids in neonatal rat. J Physiol (Lond) 455:187-204.

Chauvet N, Drian MJ, Privat A (1995) Immunocytochemical study of phenotypic plasticity of cultured dorsal root ganglion neurons during development. Int J Dev Neurosci 13:673-683.

Clarac F, Brocard F, Vinay L (2004) The maturation of locomotor networks. Prog Brain Res 143:57-66.

Coggeshall RE, Lekan HA (1996) Methods for determining numbers of cells and synapses: a case for more uniform standards of review. J Comp Neurol 364:6-15.

Commissiong JW (1983) The development of catecholaminergic nerves in the spinal cord of rat. II. Regional development. Brain Res 313:75-92.

Dumoulin A, Privat A, Gimenez y Ribotta M (2000) Transplantation of embryonic Raphe cells regulates the modifications of the GABAergic phenotype occurring in the injured spinal cord. Neuroscience 95:173-182.

Eaton MJ, Plunkett JA, Karmally S, Martinez MA, Montanez K (1998)
Changes in GAD and GABA immunoreactivity in the spinal dorsal horn after peripheral nerve injury and promotion of recovery by lumbar transplant of immortalized serotonergic precursors. J Chem Neuroanat 16:57-72.

Ganguly K, Schinder AF, Wong ST, Poo M (2001) GABA itself promotes the developmental switch of neuronal GABAergic responses from excitation to inhibition. Cell 105:521-532.

Gao BX, Stricker C, Ziskind-Conhaim L (2001) Transition from GABAergic to glycinergic synaptic transmission in newly formed spinal networks. J Neurophysiol 86:492-502.

Gaspar P, Cases O, Maroteaux L (2003) The developmental role of serotonin: news from mouse molecular genetics. Nat Rev Neurosci 4:1002-1012.

Glover JC (2000) Development of specific connectivity between premotor neurons and motoneurons in the brain stem and spinal cord. Physiol Rev 80:615-647.

Gotz M, Bolz J (1994) Differentiation of transmitter phenotypes in rat cerebral cortex. Eur J Neurosci 6:18-32.

Hayashi T, Mendelson B, Phelan KD, Skinner RD, Garcia-Rill E (1997) Developmental changes in serotonergic receptor-mediated modulation of embryonic chick motoneurons in vitro. Dev Brain Res 102:21-33.

Hillion J, Catelon J, Raid M, Hamon M, De Vitry F (1994) Neuronal localization of $5-\mathrm{HT}_{1 \mathrm{~A}}$ receptor mRNA and protein in rat embryonic brain stem cultures. Brain Res Dev Brain Res 79:195-202.

Hokfelt T, Arvidsson U, Cullheim S, Millhorn D, Nicholas AP, Pieribone V, Seroogy K, Ulfhake B (2000) Multiple messengers in descending serotonin neurons: localization and functional implications. J Chem Neuroanat 18:75-86.

Jackson DA, White SR (1990) Receptor subtypes mediating facilitation by serotonin of excitability of spinal motoneurons. Neuropharmacology 29:787-797.

Koe BK, Weissman A (1966) p-Chlorophenylalanine: a specific depletor of brain serotonin. J Pharmacol Exp Ther 154:499-516.

Koo SJ, Pfaff SL (2002) Fine-tuning motor neuron properties: signaling from the periphery. Neuron 35:823-826.

Lauder JM, Liu J, Devaud L, Morrow AL (1998) GABA as a trophic factor for developing monoamine neurons. Perspect Dev Neurobiol 5:247-259.

Lauder JM, Liu J, Grayson DR (2000) In utero exposure to serotonergic drugs alters neonatal expression of $5-\mathrm{HT}_{1 \mathrm{~A}}$ receptor transcripts: a quantitative RT-PCR study. Int J Dev Neurosci 18:171-176.

Leitch E, Coaker J, Young C, Mehta V, Sernagor E (2005) GABA type-A activity controls its own developmental polarity switch in the maturing retina. J Neurosci 25:4801-4805.

Luo X, Persico AM, Lauder JM (2003) Serotonergic regulation of somatosensory cortical development: lessons from genetic mouse models. Dev Neurosci 25:173-183.

Ma W, Behar T, Barker JL (1992) Transient expression of GABA immunoreactivity in the developing rat spinal cord. J Comp Neurol 325:271-290.

Marlier L, Teilhac JR, Cerruti C, Privat A (1991) Autoradiographic mapping of $5-\mathrm{HT}_{1}, 5-\mathrm{HT}_{1 \mathrm{~A}}, 5-\mathrm{HT}_{1 \mathrm{~B}}$ and $5-\mathrm{HT}_{2}$ receptors in the rat spinal cord. Brain Res 550:15-23.

Marty S, Berninger B, Carroll P, Thoenen H (1996) GABAergic stimulation regulates the phenotype of hippocampal interneurons through the regulation of brain-derived neurotrophic factor. Neuron 16:565-570.

Mears SC, Frank E (1997) Formation of specific monosynaptic connections between muscle spindle afferents and motoneurons in the mouse. J Neurosci 17:3128-3135.

Miquel MC, Kia HK, Boni C, Doucet E, Daval G, Matthiessen L, Hamon M, Verge D (1994) Postnatal development and localization of 5- $\mathrm{HT}_{1 \mathrm{~A}}$ receptor mRNA in rat forebrain and cerebellum. Brain Res Dev Brain Res 80:149-157.

Muramoto T, Mendelson B, Phelan KD, Garcia-Rill E, Skinner RD, Puskarich-May C (1996) Developmental changes in the effects of serotonin and $N$-methyl-D-aspartate on intrinsic membrane properties of embryonic chick motoneurons. Neuroscience 75:607-618.

Norreel JC, Pflieger JF, Pearlstein E, Simeoni-Alias J, Clarac F, Vinay L (2003) Reversible disorganization of the locomotor pattern after neonatal spinal cord transection in the rat. J Neurosci 23:1924-1932.

Owens DF, Kriegstein AR (2002) Is there more to GABA than synaptic inhibition? Nat Rev Neurosci 3:715-727.

Phelps PE, Alijani A, Tran TS (1999) Ventrally located commissural neu- 
rons express the GABAergic phenotype in developing rat spinal cord. J Comp Neurol 409:285-298.

Rajaofetra N, Sandillon F, Geffard M, Privat A (1989) Pre- and post-natal ontogeny of serotonergic projections to the rat spinal cord. J Neurosci Res 22:305-321.

Ritter B, Zhang W (2000) Early postnatal maturation of $\mathrm{GABA}_{\mathrm{A}}$-mediated inhibition in the brainstem respiratory rhythm-generating network of the mouse. Eur J Neurosci 12:2975-2984.

Rorig B, Sutor B (1996) Serotonin regulates gap junction coupling in the developing rat somatosensory cortex. Eur J Neurosci 8:1685-1695.

Takahashi T, Berger AJ (1990) Direct excitation of rat spinal motoneurones by serotonin. J Physiol (Lond) 423:63-76.

Talley EM, Sadr NN, Bayliss DA (1997) Postnatal development of serotonergic innervation, $5-\mathrm{HT}_{1 \mathrm{~A}}$ receptor expression, and $5-\mathrm{HT}$ responses in rat motoneurons. J Neurosci 17:4473-4485.

Tramu G, Pillez A, Leonardelli J (1983) Serotonin axons of the ependyma and circumventricular organs in the forebrain of the guinea pig. An immunohistochemical study. Cell Tissue Res 228:297-311.

Tran TS, Alijani A, Phelps PE (2003) Unique developmental patterns of GABAergic neurons in rat spinal cord. J Comp Neurol 456:112-126.

Verge D, Calas A (2000) Serotoninergic neurons and serotonin receptors: gains from cytochemical approaches. J Chem Neuroanat 18:41-56.

Vinay L, Brocard F, Clarac F, Norreel JC, Pearlstein E, Pflieger JF (2002) Development of posture and locomotion: an interplay of endogenously generated activities and neurotrophic actions by descending pathways. Brain Res Brain Res Rev 40:118-129.

Wang MY, Dun NJ (1990) 5-Hydroxytryptamine responses in neonate rat motoneurones in vitro. J Physiol (Lond) 430:87-103.

Yamamoto Y, Henderson CE (1999) Patterns of programmed cell death in populations of developing spinal motoneurons in chicken, mouse, and rat. Dev Biol 214:60-71. 